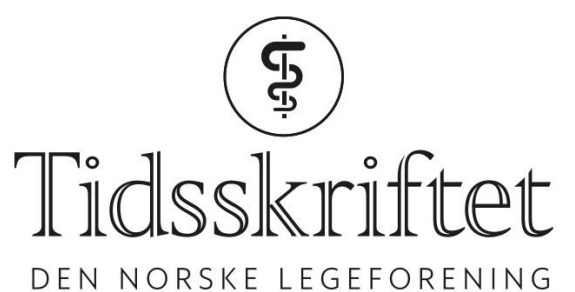

DEN NORSKE LEGEFORENING

\title{
Kan statistikk si noe om mekanismer?
}

MEDISIN OG TALL

ODD O. AALEN

E-post: o.o.aalen@medisin.uio.no

Odd O. Aalen er professor emeritus i statistikk ved Avdeling for biostatistikk ved Universitetet i Oslo. Forfatteren har fylt ut ICMJE-skjemaet og oppgir ingen interessekonflikter.

\section{MATS JULIUS STENSRUD}

Mats Julius Stensrud er lege, dr.philos. og statistiker. Han er postdok ved Harvard School of Public Health og Avdeling for biostatistikk ved Universitetet i Oslo. Forfatteren har fylt ut ICMJE-skjemaet og oppgir ingen interessekonflikter.

Klassiske analyser av randomiserte kliniske fors $ø \mathrm{k}$ forteller oss om en behandling virker, men ikke hvorfor. Kan vi finne svaret ved hjelp av medieringsanalyser?

Mediering forteller oss om årsaksmekanismer. En av historiens mest siterte statistikkartikler er skrevet av Reuben M. Baron og David A. Kenny og handler om mediering av kausale effekter (1). Men selv om artikkelen har mer enn 80 ooo siteringer i Google Scholar, er forfatternes forslag til medieringsanalyse omstridt og problematisk. Nå finnes det dessuten bedre metoder for å studere mediering.

\section{Hva er medieringsanalyse?}

Det er ingen tvil om at randomiserte kliniske forsøk kan fortelle oss om en behandling virker. Men randomiserte forsøk svarer ikke direkte på det nærliggende spørsmålet om hvorfor behandlingen virker.

For eksempel har mange randomiserte fors $\emptyset \mathrm{k}$ vist at statiner reduserer både kolesterolnivået og risikoen for hjertesykdom. Men det er likevel ikke sikkert at effekten på kolesterol fullt ut forklarer hvordan statiner kan motvirke utvikling av hjertesykdom andre mekanismer kan også bidra, blant annet kan statiner redusere inflammasjon.

Et annet eksempel er spørsmålet om effekten av terapeutisk allianse i psykologisk behandling. Mange studier hevder at en god terapeutisk allianse er essensielt for at flere typer psykologisk behandling skal ha effekt. Det kan likevel være relevant å vite hvor viktig den terapeutiske alliansen er for ulike behandlingsformer, blant annet for å tilpasse behandlingen til ulike individer.

Slike spørsmål, som altså handler om mekanismer, tilhører feltet medieringsanalyse. I de to eksemplene ovenfor er spørsmålet i hvilken grad effekten medieres av henholdsvis endring i kolesterol og terapeutisk allianse, såkalte mediatorer. Man skiller mellom en direkte effekt av behandlingen og en indirekte effekt som formidles via mediatoren. 


\section{Vanlige feil i medieringsanalyse}

Den berømte artikkelen til Baron og Kenny (1) overså essensielle forutsetninger for at en medieringsanalyse er gyldig (2). Innen fagfeltet kausal inferens har man derimot etablert presise metoder for å trekke slutninger om kausalitet og mediering (3).

Man er vant til å tenke at randomisering fullstendig beskytter mot konfundering og seleksjonsfeil, men det gjelder ikke i medieringsanalyse. Baron og Kenny overså dette viktige problemet (2) og diskuterte ikke den essensielle forutsetningen at vi må justere for alle felles årsaker til mediatoren og utfallet. I eksempelet om psykoterapi betyr dette blant annet at vi må justere for faktorer som påvirker både terapeutisk allianse og det klinisk relevante utfallet, la oss si livskvalitet. Man kan lett forestille seg at slike bakenforliggende faktorer eksisterer, for eksempel kan pasientens sosiale kompetanse påvirke både den terapeutiske alliansen og livskvaliteten. Derfor er det viktig at man forsøker å måle så mange relevante faktorer som mulig når man skal gjøre medieringsanalyser.

\section{Hvordan gjøre medieringsanalyser bedre?}

Selv om man tilstreber å måle bakenforliggende faktorer, vil det som regel også eksistere umålte faktorer. Det er ikke nødvendigvis lett å håndtere disse, men sensitivitetsanalyser kan belyse problemet. I en sensitivitetsanalyse spesifiserer man umålte faktorer, gjerne basert på fagkunnskap. Deretter beregner man hvordan de umålte faktorene kan påvirke effektstørrelsen i studien. Dette er et viktig prinsipp i kausal inferens, og metoder for å utføre sensitivitetsanalyse i praksis er beskrevet i VanderWeeles bok (3).

I figur 1 fremstilles relasjonen mellom behandling, mediator og utfall. Poenget er å skille mellom den effekten som går direkte fra behandling til utfall, og den indirekte effekten som går via mediatoren. Konfunderende faktorer som påvirker både mediator og utfall, forstyrrer dette bildet.

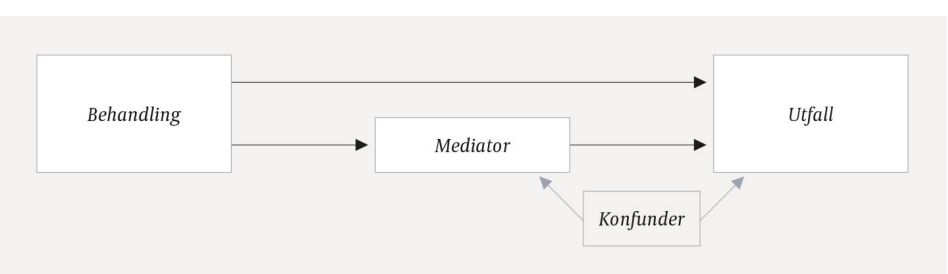

Figur 1 Relasjonen mellom behandling, mediator og utfall. Konfunderende faktorer forstyrrer relasjonen mellom mediator og utfall.

En annet problem er at mediatorer ofte måles upresist, og det kan gi uriktige estimater av direkte og indirekte effekter. Ofte blir mediatoren også målt samtidig med utfallet, noe som er et problem fordi mediatoren nødvendigvis må påvirke utfallet fremover i tid. Disse problemene kan også utforskes med sensitivitetsanalyser.

\section{Mediering gir kunnskap til å tenke nytt}

En forståelse av mekanismer hjelper oss ikke bare til å velge mellom ulike behandlingsalternativer nå, men er også essensielt for å tenke nytt om fremtidige behandlinger. Derfor er medieringsanalyse interessant. Det finnes lettleste og gode innføringer i temaet (3). Likevel er det viktig å vite at de vanlige metodene krever sterke antakelser, selv når dataene kommer fra et randomisert forsøk.

\section{LITTERATUR:}

1. Baron RM, Kenny DA. The moderator-mediator variable distinction in social psychological research: conceptual, strategic, and statistical considerations. J Pers Soc Psychol 1986; 51: 1173-82. [PubMed][CrossRef]

2. Dunn G, Bentall R. Modelling treatment-effect heterogeneity in randomized controlled trials of 
complex interventions (psychological treatments). Stat Med 2007; 26: 4719-45. [PubMed][CrossRef]

3. VanderWeele TJ. Explanation in causal inference: methods for mediation and interaction. New York, NY: Oxford University Press, 2015.

Publisert: 20. april 2020. Tidsskr Nor Legeforen. DOI: 10.4045/tidsskr.20.0001

(C) Tidsskrift for Den norske legeforening 2020. Lastet ned fra tidsskriftet.no 